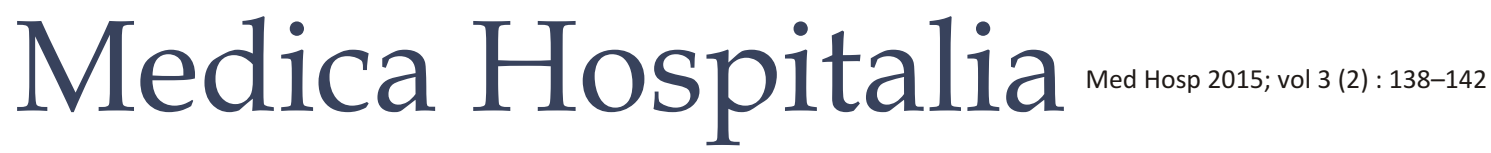

Clinical Practice

\section{Prolaps Uteri}

\section{Erwinanto}

\section{Departemen Obstetri dan Ginekologi Fakultas Kedokteran Universitas Diponegoro / RSUP Dr. Kariadi Semarang}

Prolaps organ pelvis adalah perpindahan ke bawah atau keluar salah satu organ pelvis dari lokasi normalnya. ${ }^{1}$ Perpindahan ini biasanya dibagi menjadi derajat 0 sampai 3 (atau 0 sampai 4). Derajat 3 atau 4 merupakan prolaps total atau procidentia. Berbagai istilah digunakan untuk menggambarkan prolaps organ genital antara lain:

- Sistokel adalah penurunan kandung kemih

- Sistouretrokel adalah sistokel yang mengikutsertakan uretra sebagai bagian dari kompleks organ yang prolaps

- Prolaps uteri adalah penurunan uterus dan serviks melalui kanalis vaginalis menuju introitus vagina

- Rektokel adalah protrusi rektum menuju lumen vagina posterior

- Enterokel adalah herniasi usus halus menuju lumen vagina

Salah satu baku emas untuk menentukan stadium prolaps adalah Pelvic Organ Prolapse Quantification (POPQ) yang mengukur hiatus genitalia, korpus perineal, dan panjang vagina total. ${ }^{2}$ Hiatus genitalia diukur dari pertengahan meatus uretra eksternal hingga posterior garis tengah himen. Badan perineal diukur dari batas posterior hiatus genital hingga pembukaan mid anal. Panjang vagina total adalah kedalaman terbesar dari vagina dalam $\mathrm{cm}$ saat apeks vagina direduksi hingga posisi normal. Semua pengukuran kecuali panjang vagina total diukur saat pasien mengejan.

Sistem pembagian stadium prolaps organ pelvik menurut ICS

Stadium 0 : titik Aa, Ap, Ba, dan Bp semuanya $-3 \mathrm{~cm}$ dan titik yang lain $(C, D) \leq-(X-2) \mathrm{cm}$

Stadium I : kriteria stadium 0 tidak dipenuhi dan ujung prolaps yang terendah $<-1 \mathrm{~cm}$

Stadium II : ujung terendah prolaps $\geq-1 \mathrm{~cm}$, namun $\leq$ $+1 \mathrm{~cm}$

Stadium III : ujung terendah prolaps $>+1 \mathrm{~cm}$, namun $<+(\mathrm{X}-2) \mathrm{cm}$

Stadium IV : ujung terendah prolaps $\geq+(X-2) \mathrm{cm}$ *) $X=$ panjang total vagina dalam $\mathrm{cm}$ pada stadium 0 , III, dan IV.

\section{Epidemiologi}

Defek jaringan penyokong pelvis relatif sering dan meningkat seiring usia dan paritas. Di Amerika Serikat,

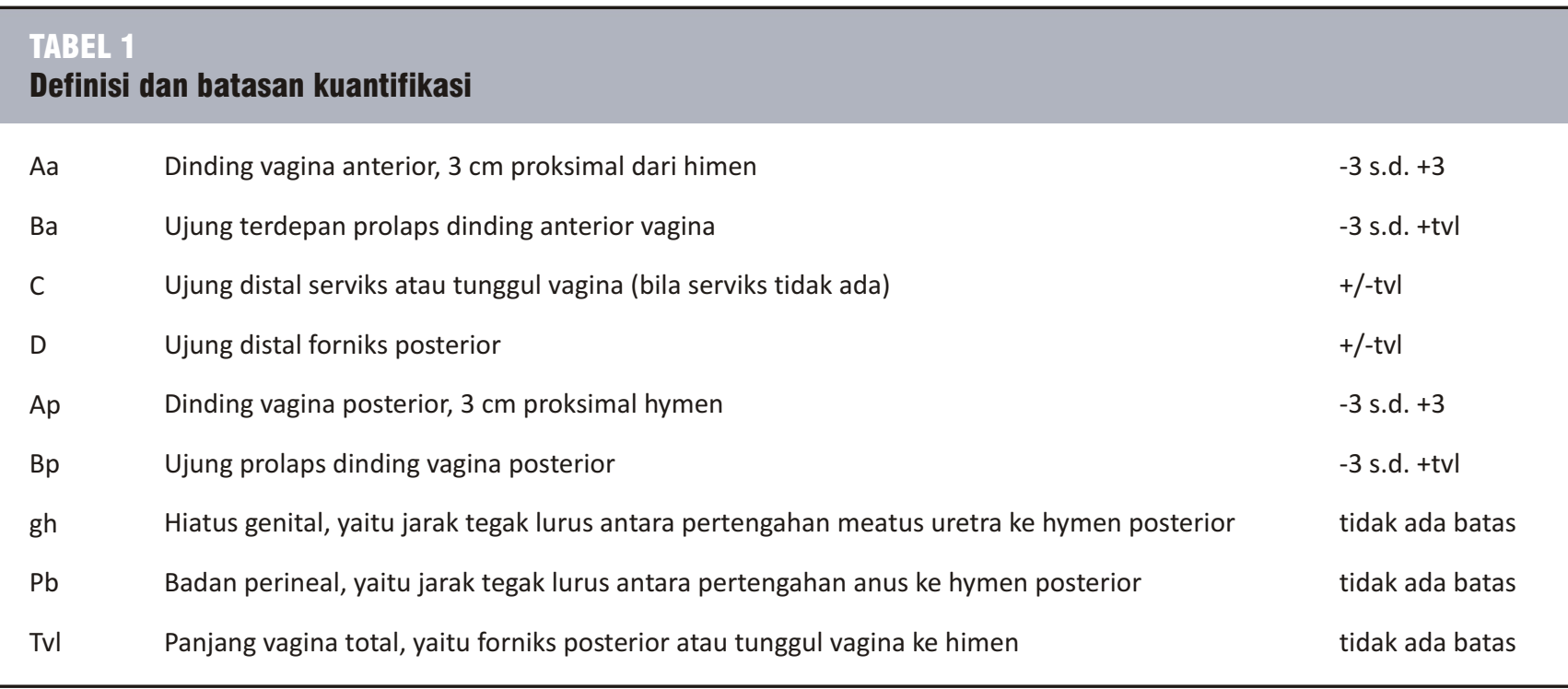


studi dari 16.000 pasien menunjukkan frekuensi prolaps uteri sebesar $14,2 \%$. Rerata usia dilakukannya bedah untuk prolaps organ uteri adalah 54,6 tahun. Perbedaan frekuensi berdasar ras diperkirakan berhubungan dengan komponen genetik. Prolaps uteri paling sering terjadi pada multipara (sekitar $>50 \%$ ) dan wanita menopause. Prolaps terkadang terjadi pada wanita nullipara atau wanita muda (sekitar $2 \%$ untuk prolaps simtomatik) dan jarang terjadi pada neonatus. ${ }^{1}$

\section{Etiologi $^{1}$}

Kondisi yang berhubungan dengan prolaps uteri antara lain:

- Trauma obstetrik (meningkat dengan multiparitas, ukuran janin lahir per vaginam) akibat peregangan dan kelemahan jaringan penyokong pelvis

- Kelemahan kongenital dari jaringan penyokong pelvis (berhubungan dengan spina bifida pada neonatus)

- Penurunan kadar estrogen (contohnya menopause) berakibat hilangnya elastisitas struktur pelvis

- Peningkatan tekanan intraabdominal, contohnya obesitas, penyakit paru kronik, asma

- Varian anatomi tertentu seperti wanita dengan diameter transversal pintu atas panggul yang lebar atau pintu atas panggul dengan orientasi vertikal yang kurang, serta uterus yang retrograde.

\section{Patofisiologi}

Prolaps uteri diakibatkan oleh kelemahan jaringan penyokong pelvis, meliputi otot, ligamen, dan fasia. Pada dewasa, kondisi ini biasanya disebabkan oleh trauma obstetri dan laserasi selama persalinan. Proses persalinan per vaginam menyebabkan peregangan pada dasar pelvis, dan hal ini merupakan penyebab paling signifikan dari prolaps uteri. Selain itu, seiring proses penuaan, terdapat penurunan kadar estrogen sehingga jaringan pelvis kehilangan elastisitas dan kekuatannya. ${ }^{3}$

Rendahnya kadar kolagen berperan penting dalam prolaps uteri, ditunjukkan oleh peningkatan risiko pada pasien dengan sindrom Marfan dan sindrom EhlersDanlos. Pada neonatus, prolaps uteri disebabkan oleh kelemahan otot atau defek persarafan pelvis secara kongenital.

\section{Diagnosis}

\section{a. Anamnesis}

Gejala diperberat saat berdiri atau berjalan dalam waktu lama dan pulih saat berbaring. Pasien merasa lebih nyaman saat pagi hari, dan gejala memberat saat siang hari. Gejala-gejala tersebut antara lain: ${ }^{1}$

- Pelvis terasa berat dan nyeri pelvis

- Protrusiatau penonjolan jaringan

- Disfungsi seksual seperti dispareunia, penurunan libido, dan kesulitan orgasme

- Nyeri punggung bawah
- Konstipasi

- Kesulitan berjalan

- Kesulitan berkemih

- Peningkatan frekuensi, urgensi, dan inkontinensia dalam berkemih

- Nausea

- Discharge purulen

- Perdarahan

- Ulserasi

\section{b. Pemeriksaan fisik}

Pemeriksaan fisik meliputi pemeriksaan pelvis lengkap, termasuk pemeriksaan rektovaginal untuk menilai tonus sfingter. Alat yang digunakan adalah spekulum Sims atau spekulum standar tanpa bilah anterior.Penemuan fisik dapat lebih diperjelas dengan meminta pasien meneran atau berdiri dan berjalan sebelum pemeriksaan. Hasil pemeriksaan fisik pada posisi pasien berdiri dan kandung kemih kosong dibandingkan dengan posisi supinasi dan kandung kemih penuh dapat berbeda 1-2 derajat prolaps. Prolaps uteri ringan dapat dideteksi hanya jika pasien meneran pada pemeriksaan bimanual. ${ }^{3}$ Evaluasi status estrogen semua pasien. Tanda-tanda menurunnya estrogen:

o Berkurangnya rugae mukosa vagina

o Sekresiberkurang

o Kulit perineum tipis

o Perineum mudah robek

Pemeriksaan fisik juga harus dapat menyingkirkan adanya kondisi serius yang mungkin berhubungan dengan prolaps uteri, seperti infeksi, strangulasi dengan iskemia uteri, obstruksi saluran kemih dengan gagal ginjal, dan perdarahan. Jika terdapat obstruksi saluran kemih, terdapat nyeri suprapubik atau kandung kemih timpani. Jika terdapat infeksi, dapat ditemukan discharge serviks purulen. ${ }^{3}$

\section{c. Laboratorium}

Pemeriksaan ditujukan untuk mengidentifikasi komplikasi yang serius (infeksi, obstruksi saluran kemih, perdarahan, strangulasi), dan tidak diperlukan untuk kasus tanpa komplikasi. Urinalisis dapat dilakukan untuk mengetahui infeksi saluran kemih. Kultur getah serviks diindikasikan untuk kasus yang disertai ulserasi atau discharge purulen. Pap smear atau biopsi mungkin diperlukan bila diduga terdapat keganasan. Jika terdapat gejala atau tanda obstruksi saluran kemih, pemeriksaan BUN dan kadar kreatinin serum dilakukan untuk menilai fungsi ginjal. ${ }^{1}$

\section{d. Radiologi}

USG pelvis dapat berguna untuk memastikan prolaps ketika anamnesis dan pemeriksaan fisik meragukan.USG juga dapat mengeksklusi 
hidronefrosis. MRI dapat digunakan untuk menentukan derajat prolaps namun tidak rutin

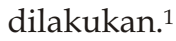

\section{Penatalaksanaan}

\section{a. Terapi Medis}

Pasien prolaps uteri ringan tidak memerlukan terapi, karena umumnya asimtomatik. Akan tetapi, bila gejala muncul, pilihan terapi konservatif lebih banyak dipilih. Sementara itu, pasien dengan prognosis operasi buruk atau sangat tidak disarankan untuk operasi, dapat melakukan pengobatan simtomatik saja. ${ }^{4}$

\section{b. Terapi Konservatif}

Pengobatan cara ini tidak terlalu memuaskan tetapi cukup membantu. Cara ini dilakukan pada prolapsus ringan tanpa keluhan, atau penderita yang masih menginginkan anak lagi, atau penderita menolak untuk dioperasi, atau kondisinya tidak mengizinkan untuk dioperasi.

\section{Latihan-latihan otot dasar panggul}

Latihan ini sangat berguna pada prolapsus ringan, terutama yang terjadi pada pasca persalinan yang belum lewat 6 bulan. Tujuannya untuk menguatkan otot-otot dasar panggul dan otot-otot yang mempengaruhi miksi. Latihan ini dilakukan selama beberapa bulan. Caranya ialah penderita disuruh menguncupkan anus dan jaringan dasar panggul seperti biasanya setelah selesai $B A B$, atau penderita disuruh membayangkan seolah-oleh sedang miksi dan tiba-tiba menahannya. Latihan ini menjadi lebih efektif dengan menggunakan perineometer menurut Kegel. Alat ini terdiri atas obrturator yang dimasukkan ke dalam vagina, dan yang dengan suatu pipa dihubungkan dengan suatu manometer. Dengan demikian, kontraksi otot-otot dasar panggul dapat diukur. ${ }^{5}$

\section{Penatalaksanaan dengan pessarium}

Pengobatan dengan pessarium sebenarnya hanya bersifat paliatif, yaitu menahan uterus di tempatnya selama dipakai. Oleh karena itu, jika pessarium diangkat, timbul prolapsus lagi.Ada berbagai macam bentuk dan ukuran pessarium. Prinsip pemakaian pessarium adalah bahwa alat tersebut mengadakan tekanan pada dinding vagina bagian atas, sehingga bagian dari vagina tersebut berserta uterus tidak dapat turun dan melewati vagina bagian bawah. Jika pessarium terlalu kecil atau dasar panggul terlalu lemah, pessarium dapat jatuh dan prolapsus uteri akan timbul lagi. Pessarium yang paling baik untuk prolapsus genitalis ialah pessarium cincin, terbuat dari plastik. Jika dasar panggul terlalu lemah dapat digunakan pessarium Napier. Pessarium ini terdiri atas suatu gagang (stem) dengan ujung atas suatu mangkok (cup) dengan beberapa lubang, dan di ujung bawah 4 tali. Mangkok ditempatkan di bwah serviks dan tali-tali dihubungkan dengan sabuk pinggang untuk memberi sokongan kepada pessarium. Sebagai pedoman untuk mencari ukuran yang cocok, diukur dengan jari jarak antara forniks vagina dengan pinggir atas intraoitus vagina. Ukuran tersebut dikurangi dengan $1 \mathrm{~cm}$ untuk mendapatkan diameter dari pessarium yang dipakai. ${ }^{5}$

Pessarium diberi zat pelicin dan dimasukkan miring sedikit ke dalam vagina. Setelah bagian atas masuk ke dalam vagina, bagian tersebut ditempatkan ke forniks vagina posterior. Untuk mengetahui setelah dipasang, apakah ukuran pessarium cocok atau tidak, penderita disuruh mengejan atau batuk. Jika pessarium tidak keluar, penderita disuruh jalan-jalan, apabila ia tidak merasa nyeri, pessarium dapat dipakai terus.

Pasien yang menggunakan pessarium harus mempunyai vagina yang well-esterogenized. Pasien postmenopause sebaiknya diberikan terapi sulih hormon, atau sebagai alternatif, dapat digunakan esterogen topikal intravaginal, 4-6 minggu sebelum pemasangan pessarium, sehingga saat pemasangan pessarium pasien dapat merasa nyaman, meningkatkan komplians, serta pemakaian dapat lebih lama. Terapi sulih esterogen dapat membantu mengurangi kelemahan otot dan jaringan penghubung lainnya yang menyokong uterus. Esterogen juga dapat memperlambat terjadinya prolaps lebih lanjut, dan dapat mencegah terjadinya iritasi pada serviks, kandung kemih, dan rektum (tergantung bagian mana yang prolaps dahulu), juga esterogen dapat membantu proses penyembuhan pada wanita yang menjalani proses operasi prolaps vagina. Ada beberapa efek samping pemakaian esterogen, antara lain meningkatkan risiko pembekuan darah, penyakit empedu, dan kanker payudara. Pemakaiannya pun harus dengan pengawasan dokter.

Indikasi penggunaan pessarium adalah :

a. Kehamilan

b. Bila penderita belum siap untuk dilakukan operasi

c. Sebagai terapi tes, menyatakan bahwa operasi harus dilakukan

d. Penderita menolak untuk dioperasi, lebih memilih terapi konservatif

e. Untuk menghilangkan gejala simptom yang ada, sambil menunggu waktu operasi dapat dilakukan. 
Kontraindikasi terhadap pemakaian pessarium ialah:

a. Radang pelvis akut atau subakut
b. Karsinoma

Komplikasi penggunaan pessarium ada beberapa, antara lain :

a. Penyakit inflamasi akut pelvis

b. Nyeri setelah insersi

c. Rekuren vaginitis

d. Fistula vesikovaginal

\section{c. Terapi Operatif}

Prolaps uteri biasanya disertai dengan prolaps vagina. Maka, jika dilakukan pembedahan untuk prolapsus uteri, prolapsus vagina perlu ditangani pula. Ada kemungkinan terdapat prolapsus vagina yang membutuhkan pembedahan, padahal tidak ada prolaps uteri, atau sebaliknya. Indikasi untuk melakukan operasi pada prolaps vagina ialah adanya keluhan. ${ }^{4}$

Terapi pembedahan pada jenis-jenis prolapsus vagina:

1. Sistokel

Operasi yang lazim dilakukan ialah kolporafi anterior. Setelah diadakan sayatan dan dinding vagina depan dilepaskan dari kandung kencing dan urethta, kandung kencing didorong ke atas, dan fasia puboservikalis sebelah kiri dan sebelah kanan dijahit digaris tengah. Sesudah dinding vagina yang berlebihan dibuang, dinding vagina yang terbuka ditutup kembali. Kolporafi anterior dilakukan pula pada urethrokel.

\section{Rektokel}

Operasi disini adalah kolpoperinoplastik. Mukosa dinding belakang vagina disayat dan dibuang berbentuk segitiga dengan dasarnya batas antara vagina dan perineum, dan dengan ujungnya pada batas atas retrokel. Sekarang fasia rektovaginalis dijahit di garis tengah, dan kemudian $m$. levator ani kiri dan kanan didekatkan di garis tengah. Luka pada dinding vagina dijahit, demikian pula otot-otot perineum yang superfisial. Kanan dan kiri dihubungkan di garis tengah, dan akhirnya luka pada kulit perineum dijahit.

\section{Enterokel}

Sayatan pada dinding belakang vagina diteruskan ke atas sampai ke serviks uteri. Setelah hernia enterokel yang terdiri atas peritoneum dilepaskan dari dinding vagina, peritoneum ditutup dengan jahitan setinggi mungkin. Sisanya dibuang dan di bawah jahitan itu ligamentum sakrouterinum kiri dan kanan serta fasia endopelvik dijahit ke garis tengah.

\section{Prolapsus uteri}

Indikasi untuk melakukan operasi pada prolapsus uteri tergantung dari beberapa faktor, seperti umur penderita, keinginannya untuk masih mendapatkan anak atau untuk mempertahankan uterus, tingkat prolapsus, dan adanya keluhan.

\section{Macam-macam Operasi :}

1. Ventrofikasasi

Pada golongan wanita yangmasih muda dan masih ingin mempunyai anak, dilakukan operasi untuk membuat uterus ventrofiksasi dengan cara memendekkan lIgamentum rotundum atau mengikat ligamentum rotundum ke dinding perut atau dengan cara operasi Purandare. ${ }^{4}$

\section{Operasi Manchester}

Pada operasi ini biasanya dilakukan amputasi serviks uteri, dan penjahitan ligamentum kardinale yang telah dipotong, di muka serviks; dilakukan pula kolporafia anterior dan kolpoperioplastik. Amputasi serviks dilakukan untuk memperpendek serviks yang memanjang (elongasi colli). Tindakan ini dapat menyebabkan infertilitas, abortus, partus prematur, dan distosia servikalis pada persalinan. Bagian yang terpenting dari operasi Menchester adalah penjahitan ligamentum kardinale di depan serviks karena dengan tindakan ini ligamentum kardinale diperpendek, sehingga uterus akan terletak dalam posisi anteversifleksi, dan turunnya uterus dapat dicegah. ${ }^{4}$

\section{Histerektomi vaginal}

Operasi ini tepat untuk dilakukan pada prolaps uteri tingkat lanjut, dan pada wanita menopause. Keuntungannya adalah pada saat yang sama dapat dilakukan operasi vagina lainnya (seperti anterior dan posterior kolporafi dan perbaikan enterokel), tanpa memerlukan insisi di tempat lain maupun reposisi pasien. Saat pelaksanaan operasi, harus diperhatikan dalam menutup cul-de-sac dengan menggunakan kuldoplasti McCall dan merekatkan fasia endopelvik dan ligamen uterosakral pada rongga vagina sehingga dapat memberikan suport tambahan. Setelah uterus diangkat, puncak vagina digantungkan pada ligamentum sakrouterina kanan kiri, atas pada ligamentum infundibulo pelvikum, kemudian operasi akan dilanjutkan dengan kolporafi anterior dan kolpoperineorafi untuk mencegah prolaps vagina di kemudian hari. ${ }^{4}$

\section{Kolpokleisis (Operasi Neugebauer-Le Fort)}

Pada waku obat-obatan serta pemberian anestesi dan perawatan pra/pasca operasi belum baik untuk wanita tua yang secara seksual tidak aktif, dapat 
dilakukan operasi sederhana dengan men jahitkan dinding vagina depan dengan dinding belakang, sehingga lumen vagina tertutup dan uterus letaknya di atas vagina. Akan tetapi, operasi ini tidak memperbaiki sistokel dan rektokelnya sehingga dapat menimbulkan inkontinensia urine. Obstipasi serta keluhan prolaps lainnya juga tidak hilang. ${ }^{4}$

\section{Pencegahan}

Pemendekan waktu persalinan, terutama kala pengeluaran dan kalau perlu dilakukan elektif (seperti ekstraksi forceps dengan kelapa sudah di dasar panggul), membuat episiotomi, memperbaiki dan mereparasi luka atau kerusakan jalan lahir dengan baik, memimpin persalinan dengan baik agar dihindarkan penderita meneran sebelum pembukaan lengkap betul, menghindari paksaan dalam pengeluaran plasenta (perasat Crede), mengawasi involusi uterus pasca persalinan tetap baik dan cepat, serta mencegah atau mengobati hal-hal yang dapat meningkatkan tekanan intraabdominal seperti batuk-batuk yang kronik, merokok, mengangkat benda-benda berat. Pada wanita sebaiknya melakukan senam Kegel sebelum dan setelah melahirkan. Selain itu usia produktif dianjurkan agar penderita jangan terlalu banyak punya anak atau sering melahirkan. Untuk wanita dengan IMT diatas normal, sebaiknya menurunkan berat badan dengan olahraga, serta diet yang tinggi serat. ${ }^{3}$

\section{Komplikasi}

Pessarium dapat menyebabkan vaginitis, perdarahan, ulserasi, obstruksi saluran kemih dengan retensi, fistula, dan erosi ke dalam kandung kemih atau rektum. Sebagian besar komplikasi diakibatkan pemakaian pessarium yang terlalu lama tanpa kontrol. Perdarahan abdomen adalah komplikasi yang dapat terjadi pada sakrokolpopeksi. Perlukaan pada pleksus vena presakral atau arteri sakro media pada saat operasi dapat terjadi. ${ }^{4}$

\section{Prognosis}

Bila prolaps uteri tidak ditatalaksana, maka secara bertahap akan memberat. Prognosis akan baik pada pasien usia muda, dalam kondisi kesehatan optimal (tidak disertai penyakit lainnya), dan IMT dalam batas normal. Prognosis buruk pada pasien usia tua, kondisi kesehatan buruk, mempunyai gangguan sistem respirasi (asma, PPOK), serta IMT diatas batas normal. Rekurensi prolaps uteri setelah tindakan operasi sebanyak $16 \%{ }^{3}$

\section{DAFTAR PUSTAKA}

1. Rajan S, Kohli N. Diagnosis and evaluation of urinary incontinence and pelciv organ prolapse. In: Ghoniem G, Davila $\mathrm{W}$, editors. Practical guide to female pelvic medicine. London: Taylor \& Francis; 2006. p. 63-78.

2. DeLancey JOL. Anatomy. In: Cardozo L, Staskin D, editors. Textbook of female urology and urogynecology. London: Informa Healthcare; 2001.p. 115-26.

3. Norton PA. Uterine and vaginal vault prolapse. In: Zimmern PE, Norton PA, Haab F, Chapple CCR, editors. Vaginal surgery for incontinence prolapse. London: Springer - Verlag; 2006. p. 15568 .

4. Sheth S, Studd J. Vaginal hysterectomy. London: Taylor \& Francis; 2003.

5. Farell SA. Pessaries in clinical practice. London: SpringerVerlag;2006. 